\title{
Within these hyperporous walls: An examination of a rebundled online learning model of higher education
}

Paula Shaw

University of Derby, Online Learning (InterProfessional Services), United Kingdom

\section{Marlies Gration}

University of Derby, Digital and Enterprise Learning, United Kingdom

\section{Pauline Green}

University of Derby, Online Learning (Health and Social Care), United Kingdom

\section{Christine Rhodes}

University of Derby, Online Learning (Counselling and Psychotherapy), United Kingdom

David Sheffield

University of Derby, Online Learning (Psychology), United Kingdom

\section{Julie Stone}

University of Derby, External Affairs, United Kingdom

\begin{abstract}
Through this paper, we explore unbundling, the separation of various aspects of education, resources, teaching and assessment (Ossiannilsson et al., 2015) and rebundling, where these activities are "recombined into new configurations with little loss of functionality" (Ge et al., 2004, p. 1). We chart the evolution of online learning at the University of Derby, from a small-scale learning and certification bundle to a rebundled online university experience. In this rebundled model, a bespoke department is responsible for the operationalisation and quality of the university's online experience. Firstly, we established the quality impact of this model, using higher education institution (HEI) value drivers. Secondly, focus groups explored macro (national), meso (institutional) and micro (practice) issues from strategic manager, academic and student experience perspectives. To facilitate discussion about the online university experience, we used a new conceptual pedagogic realignment with organisational priorities and horizon emergent technologies (PROPHET) framework. Based on our findings, we make recommendations to HEIs that are considering rebundling online learning. These include the equitable data capture and analysis of online student demographics; consideration of academic well-being and training; and the university-wide benefits obtained from knowledge exchange with online professionals, in relation to futurefocused technologies and policymaking.
\end{abstract}

Implications for practice or policy:

- HEIs should be equitable in their data capture and analysis processes, incorporating all online student and learner demographics.

- HEIs should seek out and utilise the expertise of online professionals in institutional policymaking.

- HEIs should refocus academic workload planning and training to include online learning.

- HEIs should engage in evidence-based knowledge exchange with online professionals to ensure a future-focused cohesive university experience.

Keywords: sourcing, rebundling, university experience, online expertise, online quality

\section{Introduction}

Traditionally, a degree certificate provides prospective employers with a measure of graduates' skills and intelligence. Conventionally, the degree holds the highest value for graduates entering the job market. However, in the latter part of the 20th century, the concept of employment began to change. Work became more transient, and jobs were no longer for life (Tamkin \& Hillage, 1999). Employers asked those in work 
to re-evaluate, retrain and diversify, in order to keep up with younger, technologically skilled co-workers. Thus, the demand for part-time distance learning grew.

For clarity of language, when referring to individuals studying for a degree, we use the term students, for those who have achieved the degree, graduates and those who study for continuing professional development (CPD) purposes, learners. We call full-time campus-based programmes traditional, and we use the umbrella term online learning when referring to open, distance or e-learning courses that target part-time students or learners.

As societal technology became more affordable and widespread, higher education institutions (HEIs) saw it as a vehicle to meet the growing demand for higher education (HE). To facilitate this, HEIs used their existing information technology (IT) infrastructure to turn distance learning into online learning. Therefore, internal and societal technology enabled a hyperporosity that dissolved the divide between universities and society (McCowan, 2017).

Alongside stable technology, opportunities arose to separate aspects of education, resources, teaching and assessment. This is known as unbundling (Ossiannilsson et al., 2015). However, there are many educational definitions of unbundling, as it occurs at multiple levels within the sector. We focus on unbundling within HE, of the University of Derby's curricula and academic roles, and take Swinnerton et al.'s (2020, p. 20) definition of unbundling as "flexible online courses and qualifications, delivered in new configurations of providers and partnerships" to underpin our model. Unbundling the curricula, draws on the business process of tying products and services together to create bundles, with the most profitable bundles called primary bundles. Thereafter, these bundles can be rebundled, "recombined into new configurations with little loss of functionality" (Ge et al., 2004, p. 1) to produce experiences.

Operationalising these experiences requires a scalable solution and a method of increasing revenues without increasing resources or negatively impacting quality. To achieve these goals, HEIs use cost-effective sourcing models to unbundle traditional academic roles (Whitchurch, 2008). This involves making decisions about which activities (products and services) to execute in-house (insource), which to buy from outside (outsource) and which to source from other countries (offshore). As a rule, activities that are "valuable, rare, difficult-to-imitate and difficult-to-substitute" (Ge et al., 2004, p. 17) remain insourced and deeply embedded.

HEIs also need to monitor quality. Ossiannilsson et al. (2015) suggested that monitoring the quality of online learning is a complex process, requiring stakeholders who understand the macro (national and international), meso (institutional) and micro (practice) levels of delivery.

\section{Unbundling and rebundling in $\mathrm{HE}$}

Given that operationalising online learning at scale entails sourcing decisions, many HEIs have found it beneficial to outsource academic roles and free up traditional academic time for specialised duties, such as research. Furthermore, outsourcing provides a broader skills base, more attuned to the needs of employers (McCowan, 2017). To help HEIs meet the demand for outsourced academic services, online programme management companies have become available for content creation, teaching, learning support, IT platforms, assessment and certification (Swinnerton et al., 2020).

Thus, the concepts of university and campus still exist as physical buildings. Exchanging products and services through technology adds a layer of porosity, so that universities become conceptual umbrellas with untidy boundaries (Rothblatt, 2012). Table 1 introduces our unbundled online university experience and concludes with our rebundled model. A detailed exploration of this unbundling and rebundling is described below. 
Table 1

Overview of HEI unbundling and rebundling

\begin{tabular}{|c|c|c|c|c|}
\hline Key concepts & \multicolumn{4}{|c|}{ Online university experience } \\
\hline $\begin{array}{l}\text { University } \\
\text { functions (Wang, } \\
1975 \text { ) }\end{array}$ & $\begin{array}{l}\text { Impart information } \\
\text { (Content \& } \\
\text { facilitation) }\end{array}$ & $\begin{array}{l}\text { Accreditation } \\
\text { (Assessment \& } \\
\text { certification) }\end{array}$ & $\begin{array}{l}\text { Coercion } \\
\text { (Student } \\
\text { support) }\end{array}$ & $\begin{array}{l}\text { Club membership } \\
\text { (Belonging \& } \\
\text { alumni) }\end{array}$ \\
\hline $\begin{array}{l}\text { HEI activities } \\
\text { reconfigured as } \\
\text { bundle }\end{array}$ & \multicolumn{2}{|c|}{$\begin{array}{l}\text { Primary bundle: } \\
\text { Learning \& certification }\end{array}$} & \multicolumn{2}{|c|}{$\begin{array}{l}\text { Secondary bundle: } \\
\text { Support \& belonging }\end{array}$} \\
\hline $\begin{array}{l}\text { Products and } \\
\text { services }\end{array}$ & $\begin{array}{l}\text { Services } \\
\text { Outstanding } \\
\text { programme } \\
\text { Various content } \\
\text { Academic libraries } \\
\text { Various tutoring \& } \\
\text { authoring services }\end{array}$ & $\begin{array}{l}\text { Products } \\
\text { Reputable HEI } \\
\text { Valid \& reliable } \\
\text { assessments } \\
\text { Certification } \\
\text { (CPD \& degree) } \\
\text { Professional } \\
\text { body } \\
\text { endorsement } \\
\text { (CPD \& degree) }\end{array}$ & $\begin{array}{l}\text { Services } \\
\text { Trimester } \\
\text { courses } \\
\text { Choice in work } \\
\text { pace } \\
\text { Online learning } \\
\text { advisors } \\
\text { (OLAs) } \\
\text { Remote access } \\
\text { to student } \\
\text { services }\end{array}$ & $\begin{array}{l}\text { Products } \\
\text { Alumni - global } \\
\text { clubs } \\
\text { Mobility between } \\
\text { HEIs }\end{array}$ \\
\hline $\begin{array}{l}\text { Technologies that } \\
\text { facilitate porosity }\end{array}$ & \multicolumn{2}{|c|}{$\begin{array}{l}\text { Virtual learning environments (VLEs) } \\
\text { Learning technologies } \\
\text { Massive open online courses } \\
\text { (MOOCs) } \\
\text { Publisher websites } \\
\text { Records of achievements, e.g., } \\
\text { PeopleSoft }\end{array}$} & \multicolumn{2}{|c|}{$\begin{array}{l}\text { Marketing website } \\
\text { Customer relations management } \\
\text { system } \\
\text { MOOCs }\end{array}$} \\
\hline \multirow{4}{*}{$\begin{array}{l}\text { New quality drivers } \\
\& \text { measures of } \\
\text { impact (Pathak \& } \\
\text { Pathak, 2010) }\end{array}$} & \multicolumn{4}{|c|}{ Drivers } \\
\hline & $\begin{array}{l}\text { Content quality } \\
\text { Learner \& student } \\
\text { evaluations of } \\
\text { teaching } \\
\text { Academic } \\
\text { workload } \\
\text { performance }\end{array}$ & $\begin{array}{l}\text { Quality of } \\
\text { achievements } \\
\text { Research \& } \\
\text { publications }\end{array}$ & $\begin{array}{l}\text { Student } \\
\text { experience } \\
\text { management }\end{array}$ & $\begin{array}{l}\text { Brand } \\
\text { management e.g., } \\
\text { MOOCs for } \\
\text { promoting } \\
\text { university's brand, } \\
\text { course purchases } \\
\& \text { repeat } \\
\text { purchases }\end{array}$ \\
\hline & \multicolumn{4}{|c|}{ Associated impact } \\
\hline & $\begin{array}{l}\text { Institutional } \\
\text { impact surveys, } \\
\text { e.g., National } \\
\text { Student Survey }\end{array}$ & $\begin{array}{l}\text { Student success } \\
\text { e.g., } \% \text { of } \\
\text { graduate good } \\
\text { honours }\end{array}$ & $\begin{array}{l}\text { Supportive } \\
\text { university } \\
\text { experience, e.g., } \\
\text { annual \% of } \\
\text { students } \\
\text { retained }\end{array}$ & $\begin{array}{l}\text { Rank intrinsic } \\
\text { value of HEI, e.g., } \\
\text { offer to enrolment } \\
\text { conversion, } \\
\text { alumni } \\
\text { engagement }\end{array}$ \\
\hline $\begin{array}{l}\text { Systematised, } \\
\text { centralised } \\
\text { performance culture } \\
\text { (Macfarlane, 2011) }\end{array}$ & \multicolumn{4}{|c|}{$\begin{array}{l}\text { Rebundling: Cohesive online university experience } \\
\text { Centralised strategic management of online academic \& support services }\end{array}$} \\
\hline $\begin{array}{l}\text { Third space with } \\
\text { new roles } \\
\text { (Whitchurch, 2008) }\end{array}$ & \multicolumn{2}{|c|}{$\begin{array}{l}\text { Academic portfolio managers, e.g., } \\
\text { academics responsible for content, } \\
\text { delivery, supervising, research \& } \\
\text { committees, with line management \& } \\
\text { technology expertise } \\
\text { Learning \& content designers } \\
\text { Contracted academics (content authors } \\
\& \text { facilitators) }\end{array}$} & \multicolumn{2}{|c|}{$\begin{array}{l}\text { Para-academic advisors, e.g., online } \\
\text { admissions advisors support } \\
\text { enrolment, OLAs provide non- } \\
\text { academic programme support \& } \\
\text { central student services' teams } \\
\text { provide consistent remote access to } \\
\text { university-wide support }\end{array}$} \\
\hline
\end{tabular}


Wang (1975, p. 55) defined HEI products and services as "imparting information, accreditation, coercion and club membership". In contemporary language, this refers to content and facilitation, assessment and certification, student support, belonging and alumni. The most important bundle for online learners is learning and certification, composed of content and facilitation (services) to achieve assessment and certification (product). The secondary bundle, support and belonging, includes individual student support (services) to create a long-term sense of belonging and alumni (product). Assembled, the two bundles form a complete online university experience.

Unbundling traditional university experiences addresses the affordability of HE according to Wang (1975), but this does not necessarily enable learners and students to fit their studies around work. Open universities first pioneered the use of media technologies to record lectures, enabling students to choose the time and place of their studies. Since then, technologies have become more affordable and compatible, leading to greater remote access to a university education for the mature workforce (Swinnerton et al., 2020). To manage the different aspects of the online university experience, different types of technology are needed (see Table 1). To enable the learning and certification bundle, HEIs invest in VLEs, learning technologies and academic publication repositories, and an enterprise performance management system to record and monitor achievements. Similarly, to manage the support and belonging bundle, HEIs use business systems such as marketing websites and customer relations management systems. It is pertinent to note that technology is used to blur the lines between bundles; for example, MOOCs provide societal learning and enhanced brand visibility (McCowan, 2017).

Whether academic services are insourced or outsourced, HEIs are accountable for the overall service quality. Analogous with Porter's (1985) value chain model, Pathak and Pathak (2010) suggested that each university product and service can be measured according to its impact on their reputation. These measures include the number of new students and learner enrolments, the retention of students, the value students and learners place on the learning experience and the number of high-ranking graduate achievements. In recent years, outsourcing academic services has attracted speculation about the impact on HEIs, raising concerns about quality, reputation and shared governance (Sundt, 2019). McCowan (2017) asserted that this process leads to a fragmentation or multiplicity of values that do not present a cohesive university experience to students. Tight (2010) suggested that more part-time staff means that there is a diminishing number of full-time staff to carry out traditional university roles, such as attending committee meetings and advising students, leading to an increase in some academic workloads. Ruth et al. (2007) also shared a concern that academics feel too far removed from the developed materials to teach them effectively.

Whitchurch (2008) proposed a third space between insourcing and outsourcing, which employs blended roles, spanning professional and academic domains (see Table 1). In our rebundled online university model, most academic work is insourced; para-academic roles maintain the support and belonging bundle, and everything is operationalised by strategic managers within a centralised performance culture (Macfarlane, 2011). In this space, online learning quality requires the input of stakeholders, "staff and students, governments and other funders, professional bodies, employers, and the general public" that understand macro, meso and micro levels of online learning (Ossiannilsson et al., 2015, p. 32). However, most reviews take place at the meso level.

\section{Aim and research question}

Firstly, through this paper, we charted the evolution of online learning at the University of Derby from a small-scale learning and certification bundle to a rebundled online university experience. In this rebundled model, a bespoke department took responsibility for the operationalisation and quality of the university's online experience.

Secondly, we question what HEIs can learn from this experience. To achieve this, we explore the perspective of meso- and micro-level stakeholders including strategic managers, academics and student experience professionals. Through a series of focus groups, these stakeholders present their views of the online university's functions. From this, we make recommendations for HEIs that are considering adopting a rebundled model. 


\section{Operationalising the unbundled and rebundled university experience}

Having engaged with distance learning during the 2000s, the University of Derby was well positioned to observe the changing landscape. We first adopted a small-scale learning and certification model (Figure 1) with the support of external hosting platforms (O'Hagan, 2003). In 2008-2009, the university's estimated size was about 20,000 full-time students; approximately 12,000 (60\%) were mature students and approximately 646 (3.2\%) fully online (Bacsich \& O'Hare, 2009). In this model, IT Services maintained the VLE. Students and faculty academics engaged directly through the VLE, but there was no access to student services.

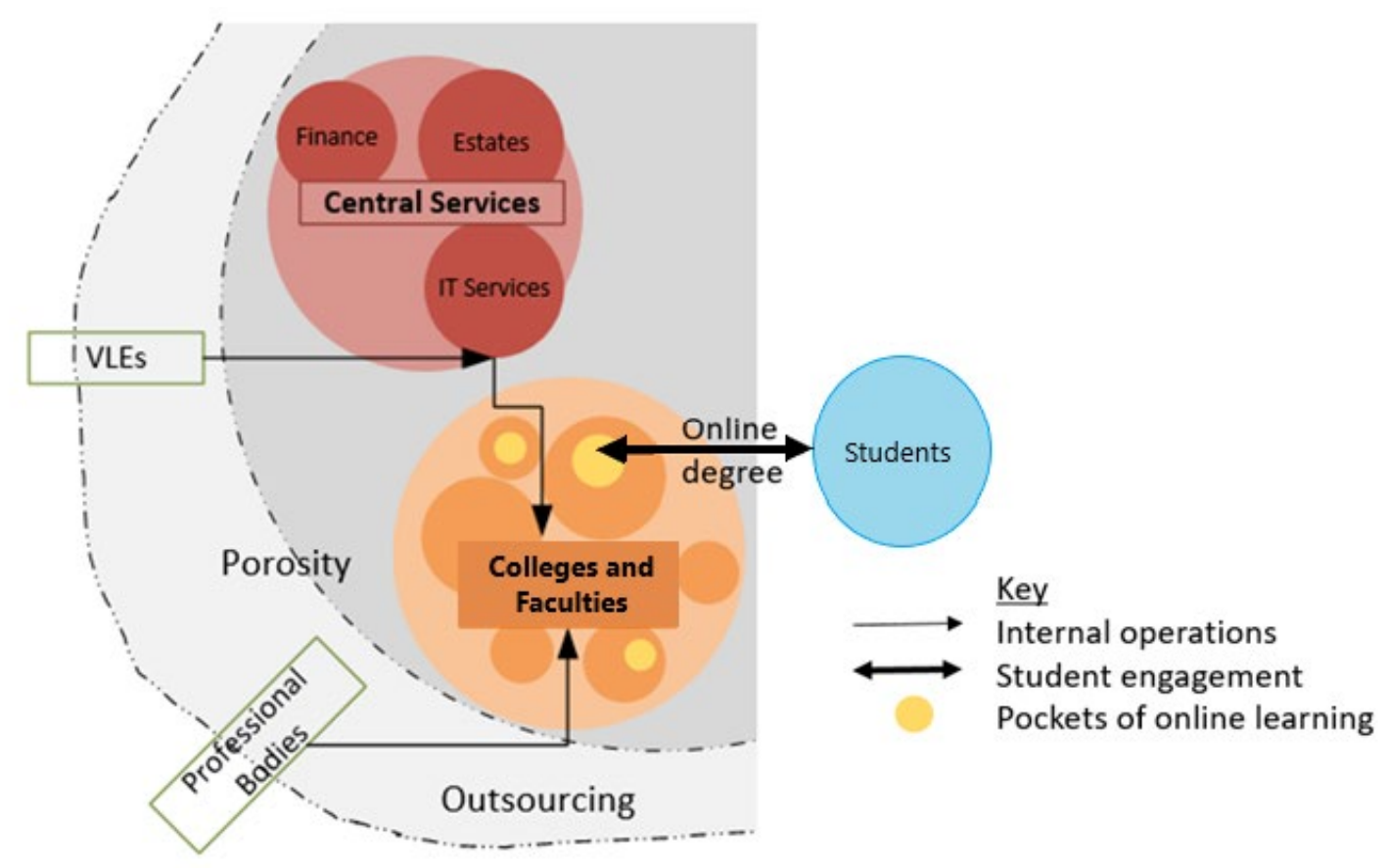

Figure 1. University of Derby's small-scale unbundled offer

However, in 2011, the Higher Education Statistics Agency (2013) reported a steep decline in the number of mature students entering United Kingdom (UK) HE; changes in the 2012 fee structure further exacerbated this problem (UK Council of International Student Affairs, 2019). Expanding online provision was identified as a means of reducing the shortfall, and a critical review of the existing provision ensued. The university arrived at a pivotal point in 2012, with a decision to either fully outsource online learning to an online programme management provider or rebundle it, using existing resources. The senior leadership team opted to rebundle and grow online learning from within the organisation, along with a small team of outsourced academics. The decision affirmed the extensive skills that already existed and the desire to retain control over the academic quality, student support, income and institutional learnings (Figure 2). In this model, online students engage with academics through the VLE, but the service and quality of that experience is managed by an online learning department. This model enables students to access online student services which, together with the learning and certification bundle, provides a cohesive university experience. 


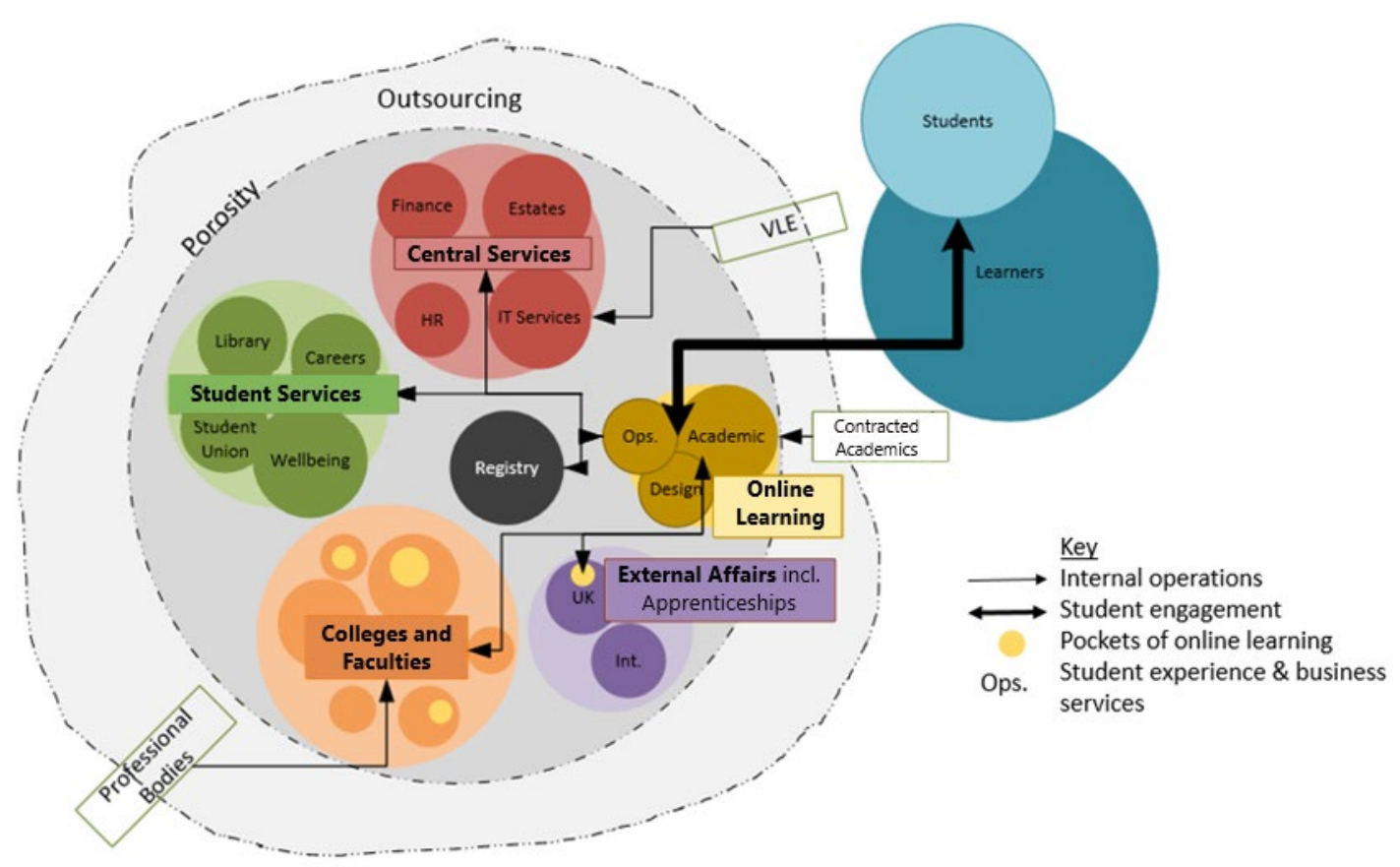

Figure 2. Rebundled university offer

This department, University of Derby Online Learning (UDOL), was equipped with an operational team comprising marketers, sales administrators, learning support advisors, a business development team, an academic team and content designers. The university shifted from the previous technology-driven unbundled approach to a student-centred online university experience. UDOL established principles to drive effective and efficient online learning, which were collectively called the online academic framework, and the university's academic board approved this framework in 2013. This framework provided agile, scalable online learning as a learning and certification bundle and, by strengthening cross-institutional services, offered the secondary support and belonging bundle at no extra cost.

The discussion below explores the rebundled model, using new value chain drivers (Pathak \& Pathak, 2010) to measure the success of UDOL's framework.

\section{Support and belonging}

In 2012, UDOL recruited admissions staff and OLAs to support the enrolment and pastoral care of online students. The admissions team were able to provide specific advice about online programmes, which resulted in a 70\% offer to enrolment conversion rate in 2019 (personal communication, November 20). Successful enrolments help to satisfy the first value driver in the chain. In 2014, the university's student well-being team initiated a service-level agreement with UDOL. They recruited two online counsellors and took the first steps in providing an equitable university experience for online students. Additional student services followed suit, offering Skype appointments and a timetable of live, interactive webinar sessions with representatives from central university services teams, namely the student union, library, study skills and careers teams. These central services are linked with social-hygiene factors and support student motivation and retention (Richardson et al., 2017). We observed an increase in student retention (calculated by total students minus withdrawals) in 2018-2019, recorded at 90\%, in comparison to traditional students at 91\% (Higher Education Statistics Agency, 2020a); successful retention is the second driver in the value chain. Notably, the reimagined online services found favour with traditional students too. Central university services teams reported online engagement from all students, particularly students on other campuses, commuter students and higher apprentices; noting that an outsourced online programme management model would not provide such benefits to students in other modes of study. 


\section{Learning and certification}

Analysis of the online experience in 2011 (Figure 1) revealed a disjointed student journey fraught with navigational difficulties. This was exacerbated by personal participation barriers, including ageing computers, poor Internet quality, disabilities and poor technology skills (O'Doherty et al., 2018; Uppal et al., 2018). Three navigational improvements were made: Firstly, an online student portal was designed to provide a single-entry point to all the university's services and provide tailored communications, rather than local information such as car park information (O'Shea et al., 2015). Like the physical campus, the online student portal acts as the reception desk, directing students to various services and classrooms. Secondly, modules were given a standardised house style for a consistent experience. Thirdly, learning was transcribed, digitised and represented through a variety of media. UDOL's learning design was underpinned by key online pedagogies such as universal design for learning and activity-driven e-tivities (Salmon, 2004). UDOL academics were expected to marry together multimedia content with accessible, networked, facilitated learning (Figure 2).

However, UDOL identified that academics needed inducting into multimedia, activity-based learning (King, 2002). When students have difficulty with module navigation and ambiguous instructions, or perceive detachment from the tutor, their learning experience is compromised (Shaw, 2018). In order to counter this, academics new to online learning engaged with facilitator-led inductions. These provided more than technical know-how, as they uncovered a hidden curriculum of unique online attributes (P. Norton \& Hathaway, 2015; Roberts, 2004). Overall, participants experienced being an online student themselves. Many external training programmes exist; yet evidence suggests that without compulsory training, teachers will continue to teach in traditional ways, reflecting their own experiences (Davis \& Rose, 2007). Over 200 academics have successfully completed our in-house compulsory inductions.

The quality of this experience is measured by the remaining value drivers. Student feedback surveys indicate that online undergraduate overall satisfaction in $2018 / 19$ was $85 \%$ and postgraduate $80 \%$ (Office for Students, 2020a), in comparison to traditional undergraduate students being $83 \%$ and postgraduate students $85 \%$ respectively (Office for Students, 2020b). These satisfy the third value driver in the chain. The final value driver is quality of achievement, which is measured by the percentage of graduates achieving good honours. UDOL reported that $61 \%$ of online undergraduates achieved good honours in 2018, compared to $68 \%$ of traditional students (Office for Students, 2019).

In the 9 years since UDOL's inception, according to the Higher Education Statistics Agency (n.d.), the University of Derby has remained at circa 20,000 traditional students, whereas UDOL has grown to a total of 4095 students according to the university's internal planning model, a growth of $522 \%$. Additionally, learner engagement with professional body (OpenupEd) endorsed MOOCs and short courses increased to 25,490 CPD days in 2018/19 (Higher Education Statistics Agency, 2020b). In conclusion, the recruitment, retention, satisfaction and achievements of online students and learners have all improved and are within $7 \%$ of traditional programmes. Taken together, these demonstrate the impact of rebundling. In the following sections, we question what HEIs can learn from this rebundled model.

\section{Methodology}

\section{Participants}

Once ethical approval was granted, we invited a purposive sample of 17 participants from a total population of 53 online learning stakeholders (i.e., 32\%) to attend focus groups; all participants were responsible for the quality of UDOL's operations and performance. Participants were placed in focus groups according to their operational roles as follows:

- Strategic management - Five senior managers from a population of 13 (i.e., 38\%), each holding a senior role within UDOL for between 4 and 7 years.

- Academic - Seven academic leads from a population of 18 (i.e., 38\%) subject specialists, each performing online leadership roles between 2 and 6 years. The group was comprised of learning and content designers, and subject specialists from psychology, health and social care, engineering, environmental management and education. 
- Student experience professionals - Five participants from the wider university support team of 22 (i.e., 23\%). Each was a committee member of UDOL's Student Experience Learning and Teaching Committee, drawn from cross-institutional roles that support the online student experience. These included representation from Technology Enhanced Learning, UDOL and the university's student experience teams.

\section{Procedure}

In order to review the online university experience, a new conceptual framework was developed in 2019 by Shaw et al. (2020) to incorporate pedagogic realignment (PR) with organisational priorities (OP) and horizon emergent technologies (HET), abbreviated to PROPHET framework. This framework created a visual model, the dynamic multi-level diffusion of innovation (DMDI) model, to bring stakeholders together from different levels of the HEI, to explore the operationalisation of online learning.

In preparation for the focus groups, the participants were provided with participant information sheets and consent forms, which included consent to being video recorded. The participants were also provided with the DMDI model, with category examples to aid reflection (Figure 3).

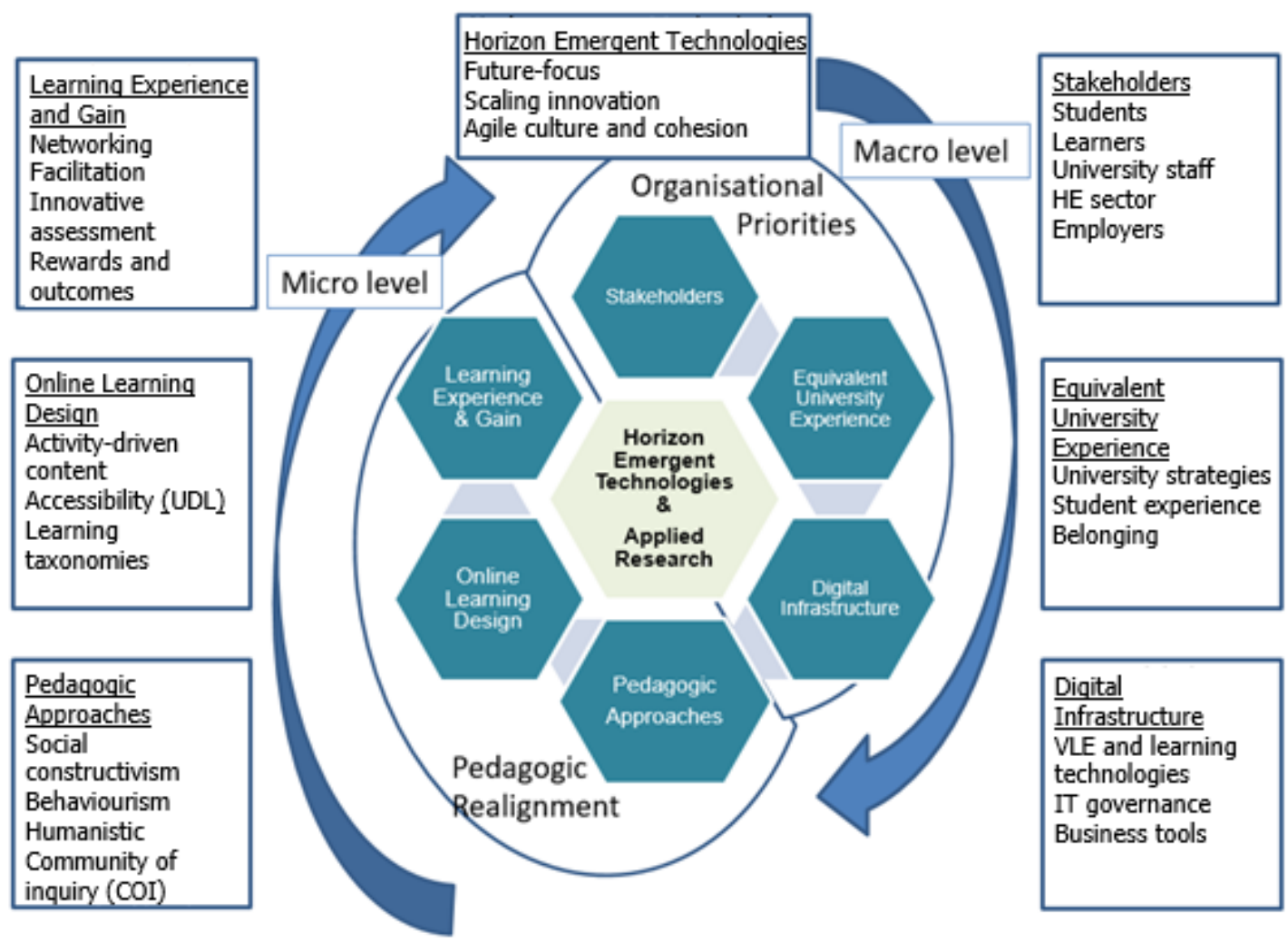

Figure 3. The DMDI model used by participants, with six categories and examples of themes in boxes

With consent agreed, we convened the three focus groups and guided the discussion, which lasted 45-60 min. During the sessions, each facilitator followed a facilitator brief to ensure consistency between the focus groups, and the participants were asked to follow guidelines including one person speaking at a time and turning off mobile phones to facilitate clearer audio capture within the video. Each participant was issued with a unique identifier code commencing with the letters FG. These identifier codes were later used to anonymise participants' quotes.

Participants systematically explored each category of the DMDI model in turn, sharing insights about organisational priorities. Discussions commenced with stakeholders at the macro HE level, moving to the institution's meso-level priorities with equivalent university experience and digital infrastructure, then continued with discussions about pedagogic realignment at the micro level, starting with pedagogic 
approaches and online learning design, and they concluded with learning experience and gain. Horizon emergent technologies were considered throughout the discourse to remain future-focused. Participants were asked to try and achieve a consensus about the most important issues for online learning. Furthermore, they could, if desired, introduce new future-focused topics within the categories for discussion. At the end of the session, participants received a written debrief and they were invited to provide feedback on the process.

\section{Analysis}

Thematic analysis (Braun \& Clarke, 2012) was used to summarise the themes. Analysis of the focus group sessions involved observation of the video recordings, uploaded to NVivo 12 software. One of us maintained the codebook and collaboratively coded all the videos with each of the others. Each one made independent notes whilst watching segments of the video, then independently classified their themes as nodes. When all the videos had been watched and coded, we counted the number of references to a node; these indicated the strength of opinion. We collaboratively named the seven significant themes, transcribed representative quotes directly from the recordings and noted relevant non-verbal communication. The focus group video recordings enabled us to capture body language and emotional expression, as supplementary analysis, to better guarantee the confirmability and trustworthiness of the findings (Saldaña, 2015).

Through the UDOL Student Experience Learning and Teaching Committee, student representatives were asked to share the findings with students and provide feedback to the committee. However, student representatives reported negligible engagement, and there was no feedback to report.

\section{Results and discussion}

The following discussion presents the challenges and opportunities facing stakeholders working in the rebundled model. We found seven significant themes that could be arranged into three overarching themes, two of which concur with the university bundles of support and belonging and learning and certification. The third provides a focus on future opportunities to improve student retention and attainment.

\section{Support and belonging}

Theme 1: The UK HE sector inequalities and disadvantages

Discussions commenced with a focus on macro HE level policies and the impact of these on academic staff, students and learners. Strategic managers and academics focused on the longitudinal education outcomes dataset, which links HE and tax data together to "chart the transition of graduates from higher education into the workplace" (Department for Education, 2017, p. 34). The participants suggested that the longitudinal education outcomes dataset on employability excludes the achievements of mature students, who work and study concurrently and aim for promotion, rather than entering the job market for the first time.

Academics expressed a challenge working with some professional bodies and their standards for accreditation and questioned whether the institution was able to positively influence professional body decisions about the reputation of online learning; one said, "It is as much about relationships, getting them in and if there is any hesitancy about online learning asking why that won't be signed off. It's as much about politics and social relationships as the standards themselves" (FG207).

Student experience professionals expressed the need for rebundled online learning to be accepted by the $\mathrm{HEI}$, as an equivalent flexible university experience, for part-time and full-time students. Furthermore, they requested support from the university in lobbying HE policymakers:

The one we are talking about at the moment is Student Finance England and how we could get them to recognise the integration of online learning, and appreciate how a campus student could be doing large elements of online learning and still be classed as full time and still be entitled to the full complement of financial support. (FG305)

This situation highlights the inequality facing online students, and it confuses the blended learning landscape (Dziuban et al., 2018). HEIs struggle to comprehend at what point blended learning becomes 
online learning, and there is a tension between classifying students as part-time or full-time against regulatory norms.

Theme 2: Tension between traditional and online delivery

Discussions moved next to meso (institution level) challenges. These discussions provided specific examples of tension between traditional and online delivery, in relation to teaching and learning strategies and policies that are designed, then retrofitted for online students. One strategic manager positioned the tension at an institutional level, suggesting a "fracture" that makes it difficult for online learning to fully meet policies designed for traditional students. The rest of the group exhibited strong acknowledgement through nodding:

We have been told to get onboard with the university's teaching and learning strategy almost as if online learning, employers and apprenticeships are not a part of it [...] we should be informing that [strategy] but it feels like it is dictated the other way round. (FG105)

Some academics felt that they had a role to play in supporting campus colleagues expand their programmes to include online opportunities (Golden, 2016; Wiss et al., 2018), thus exposing the difficulties in applying policies designed for UK traditional students (Mohr \& Shelton, 2017). One academic said: "If we are really about a virtual campus, it has to move with the times and be accessible for all" (FG202). This was responded to with agreement and positive body language.

Student experience professionals also spoke about a divide, citing a feeling of disconnect and misunderstanding of online learning that emerges from a desire to maintain the traditional student experience. For example, a student experience professional stated that the university was planning to adopt peer assisted learning (but it was unclear how these interventions would translate to an online environment and, therefore, UDOL had not yet been included in those discussions. At the same time, academics explained that it was difficult to retrofit the individual tutorial policy, Personal Academic Tutoring, to the online context, particularly when students are in different time zones with intermittent Internet connections. These concerns echo the fragmentation or multiplicity of values described by McCowan (2017).

Theme 3: Articulating online students' value of their university experience

A curriculum void was highlighted between the traditional curriculum and the needs of work-based students and learners. A strategic manager explained that if the same curriculum is used for traditional and online programmes, online students complain that the curriculum does not meet their needs:

On campus, they try to simulate the work environment, whilst we try to situate them, we are at the opposite ends of a continuum [...]. On campus, we would be saying how you do it in the workplace and online we would be saying why we are doing it in the workplace. Students are already doing the job, what they want to do is enhance it. (FG101)

Another strategic manager stated that employers talk about the missing traits of university students entering the workplace, for example, knowledge, skills and behaviours. When viewing these traits through the lens of online learning, they concluded that online students are already situated in the workplace; therefore, it is less important to teach basic employability traits. Moreover, online students expect to be challenged with complex problems and skills that prepare them for promotion.

All groups had concerns about using surveys designed for traditional students to establish online students' perceptions of their university experience. Accurately measuring internationally based online students' perceptions of the university experience is particularly challenging (Reilly et al., 2012). As the Times HE comparative surveys demonstrate, there is a marked difference in satisfaction scores attributed by students in United States of America, Europe and Japan for the same questions (Bothwell, 2020). With UDOL students in all three time zones, like-for-like comparisons against the traditional university experiences can be problematic. 


\section{Learning and certification}

Theme 4: Academic workload planning and training

The focus groups moved on to micro-level discussions about the complexity of online learning delivery, learning design and academic visibility. Academics were concerned about staff well-being and appropriate workload planning:

If we are going to move to co-delivery with campus teams, there is going to be a clashing of worlds between on campus and online, bearing in mind that all my colleagues on campus will be finished over the summer and I will be still teaching. (FG207)

Academics generally agreed that there is not a sufficient mechanism to gather the staff voice to highlight specific workload challenges. Managing competing teaching priorities was at the crux of the issue. Academics highlighted that teaching in both modes (campus and online) and throughout the year, with increased admin responsibilities, provides little focused time for research. They also found it difficult to take annual leave without disrupting aspects of module delivery. These concerns echo those of Tight (2010) and McCowan (2017), who have both suggested the need for a closer look at restructuring academic workloads in order to fulfill the academic role.

Strategic managers shared concerns that the online authoring and facilitation inductions are not integrated into the university's Postgraduate Certificate in Higher Education. They stated that the distinctions between online and campus are blurring (Martin, 2018; A. Norton \& Cakitaki, 2016; A. Norton \& Cherastidtham, 2014) and the institutional Postgraduate Certificate in Higher Education programme, designed to support new staff transitioning into teaching, did not fully meet that function.

\section{Theme 5: Evidence-based learning approaches}

There was consensus among all groups that the online academic framework was fine for 2011, but this is now too constrained, providing a limited number of approaches. Academics suggested that the framework should be updated and tiered to include consistent business as usual approaches and optionality. Additionally, academics agreed that the framework emphasises scalable learning design and this improves the usability of the VLE for everyone.

Strategic managers recognised the difficulty traditional academics have in understanding online pedagogical approaches and where to apply them. They suggested that there should be an evidence-based best practice toolkit created to support decision-making:

That [toolkit] should inform our research approach because a framework is just a framework but we should cognitively explore things and you need to understand why you chose a certain approach [...] If we are going to be market leaders, we need to understand what is best practice and apply it. (FG102)

A strategic manager highlighted differences between subjects, stating that, “One size doesn't fit all. Getting the basics right in one programme will not be the same as getting the basics right in another, but identifying the basics is difficult" (FG105). A learning designer provided an example of how this might work:

Applying a social and situated, authentic approach to an activity with one group and using a more behaviouristic approach with another, then comparing the outcomes of both groups, you can literally see for that context, what approach would work best [...] we would be pedagogically at the forefront of design. (FG301)

All groups were concerned about the perceived negative image of online learning, echoing the concerns of McCowan (2017), even though evidence suggests that students perform the same or better than in face-toface instruction (McPhee \& Söderström, 2012; Means et al., 2009; Wang, 1975). One academic member said, "There is a mindset that online means lower quality and people just don't understand all the add-ons, it's not just PowerPoints on screen, it's a whole student experience"' (FG205). 
Leading the discussion away from content to facilitation, strategic managers intensely debated the visibility of academics in online learning, suggesting that academics should be more overt about the value they add (Korving et al., 2016; Saadatmand et al., 2017). One member of the group said:

[Academic] visibility is implicit in the framework, for example, social and authentic, if you're not getting that from the academic it can be quite hard to get that just from course materials $[. .$.$] as well as that, the intergroup stuff, the empathy, that is where the academic$ sits. However, things like expertise are the very reason why students come to university, it's because they want to learn stuff, from experts, otherwise why would they be here? They may as well just learn from Facebook. [...] I think students do want those social parts of learning, but it is often as encouragement and support rather than knowledge per se. (FG104)

Theme 6: Inclusive, innovative assessments

Concluding the delivery cycle, student experience professionals were keen to see a university-wide assessment and feedback strategy applied. Academics and student experience professionals expressed the need to ensure that assessments are inclusive of all students, enabling them to reach their full potential and that UDOL needs to work harder to create a sense of belonging for disadvantaged groups (ArasaratnamSmith \& Northcote, 2017; Gao et al., 2018). A high proportion of those studying online are international students; therefore, different international contexts need to be taken into consideration when designing assignments. They saw this as a challenge and they saw an assessment disconnect within the standard core curriculum, as traditional programmes may be UK focused and designed for the full-time undergraduate market. It was suggested that adopting the Advance HE internationalisation framework (2015) would be useful to ensure that international students are not overlooked in curriculum design and assessment.

Academics also focused on opportunities for fail fast and often, defining it as deferred success, next time and not done it yet. They referred to British culture and questioned whether the UK education system sufficiently accommodates failure. A strategic manager suggested that fail fast and often and digital badges were two sides of the same coin, with digital badges providing the reward for success. Academic enthusiasm was stifled by a concern about how much tinkering with assessment one could do, concluding that realistically, innovation can only take place in formative assessments until the approach has been properly tested:

It's so difficult right, if you tinker with assessments there are so many things that can go horribly wrong and you don't want to have to explain why a whole load of students failed because you've tinkered with an assessment. (FG207)

\section{Horizon emergent technologies: Future focus on improving student retention and attainment}

Theme 7: Personalised learning and learning analytics

Conversations focused on pedagogical approaches and student support applied through personalised learning interventions and learning analytics. These discussions led to questions about the university's technologies and how these could be used to track learning, support student and improve graduate outcomes. All groups recognised that personalised learning places individualist and social constructivist approaches in contention (Martin, 2018; McLoughlin \& Lee, 2010; Office for Students, 2019; Santally \& Senteni, 2013).

Academics explored student and learner engagement and questioned how we could motivate them and increase their sense of worth:

I'm interested in that [personalised learning] and how you can use technology to give for example, automated nudges that make the learning feel more personal, and it is in effect more personal, but it doesn't require the personal intervention of the tutor. You can do it and be more efficient. (FG201)

Student experience professionals were interested to learn how personalised learning could shape the university experience with the use of learning analytics. Some academics suggested moving beyond 
learning analytics to student-led analytics and big data science; however, several academics questioned the ethics of these approaches:

Big data science is the dark side of analytics, some universities are saying that they can predict now whether their students are going to fail, just from their applications; socialeconomic backgrounds, exam results, their metadata sets. The argument for doing that is that they can put forward interventions to help those students, although I haven't heard much about the interventions yet. (FG207)

One academic stated they were aware of colleagues who are looking at such interventions: "So long as you know what you are doing with that data that's ok, it could be positive discrimination."

A strategic manager also expressed interest in learning analytics, suggesting that it could be a unique selling point for UDOL. However, the strategic management group cautioned against trying to deliver a full package of analytics and suggested that OLAs would be able to identify measurable aspects of the student experience:

With big programmes and large student numbers you must use analytics to know how to make interventions, to be able to look across a dashboard, rather than at the manual interventions we do now. If we had the analytics it would help us with decision making and motivation. (FG105)

Overall, the group's participants demonstrated positive body language and were animated when talking about future possibilities. Their discussions focused on technologies that are known and already available in the university, yet underused. This indicated that they were keen to explore future changes when given the opportunity.

\section{Recommendations}

After summarising the discussions, we concentrated on recommendations to enhance the rebundled model. This led to the following recommendations for the sector and HEIs that are considering adopting a rebundled model.

\section{Recommendation 1: A challenge for the HE sector}

Drawing on the findings from themes 1 and 3, an implication from the study is that HEIs should be equitable in their data capture and analysis processes, incorporating all online student and learner demographics. To address this, we recommend that:

- Employability needs to be clearly defined for the online audience, as most are in work and looking for promotion. HEIs should capture data about career progression and changes in job role, in addition to data about those entering the job market for the first time.

- A change to student funding is required, enabling online learning to become a more useful component of full-time student education.

Additionally, professional bodies do not appreciate that rebundled online learning meets HEI value drivers. We recommend that:

- HEIs should challenge professional bodies to accept rebundled online learning as a valid and alternative approach to traditional HE.

\section{Recommendation 2: Inclusive university experience}

In relation to theme 2, the implication is that HEIs should seek out and utilise the expertise of online professionals in institutional policymaking. We recommend that:

- HEIs should ensure that new policies will work in the online mode. 
- HEIs should consider how existing policies retrofit, to be inclusive of online students and learners.

- HEIs should recognise that online students are entitled to an equivalent university experience throughout their studies.

\section{Recommendation 3: Academic well-being, workload and training}

Reflecting on theme 4, we infer that HEIs should refocus academic workload planning and training to include online learning. Academic staff well-being is a critical factor in providing an excellent university experience; therefore, HEIs should consider:

- Incorporating online learning design and facilitation into their Postgraduate Certificate in Higher Education programmes.

- Refocusing workload planning to consider staff well-being and the rhythm and pace of teaching when working in both delivery modes (face-to-face and online).

\section{Recommendation 4: Future focus}

Themes 5, 6 and 7 focused on future learning, student retention and attainment. From these discussions, the implication is that HEIs should engage in knowledge exchange with online professionals to ensure a futurefocused cohesive university experience. We recommend that:

- HEIs should establish a toolkit of tiered evidence-based approaches that promote excellence in online learning, which is cognisant of different subject area needs.

- HEIs should establish a future-focused innovation and research culture, to understand the impact of online pedagogic and technology interventions on graduate outcomes.

\section{Conclusion}

This rebundled model presents measures of success comparable with traditional programmes, offering many benefits to HEIs that would not be acquired through an unbundled model. For online students and learners, these benefits include the support and belonging bundle in addition to the learning and certification bundle. For the HEI, the rebundled model has introduced flexible online support for all university students, an enhanced VLE and academic training to improve online content and facilitation.

However, the research design revealed some previously hidden challenges for HEIs considering the adoption of this model. We advise policymakers to make their data capture and policies more equitable. We propose that teacher training programmes are reviewed, so that they prepare new academics to work in both traditional and online modes of delivery and we suggest that academic workloads account for the complexity of working in both modes of delivery.

These insights are limited by the fact that only one rebundled model within one UK university was examined. We propose that a study of multiple rebundled HEIs would further strengthen the recommendation. Furthermore, to enable participants to hear challenges from different levels of the organisation, focus groups should be mixed and involve online students and learners from the outset. Following the sessions, feedback revealed that participants wanted more time to discuss certain categories; therefore, follow-up meetings would enable stakeholders to explore selected categories in more detail.

Finally, we believe that the rebundled online university experience provides more benefits than deficits for HEIs. This model provides a cohesive online university experience of support and belonging, learning and certification, comparable with traditional programmes. Furthermore, it derives its HE ethos from the university's strategy and values, avoiding the fragmentation or multiplicity of values that create an inconsistent online university experience. 


\section{References}

Advance HE. (2015). Equality in higher education: Statistical report 2015. https://www.advancehe.ac.uk/knowledge-hub/equality-higher-education-statistical-report-2015

Arasaratnam-Smith, L. A., \& Northcote, M. (2017). Community in online higher education: Challenges and opportunities. Electronic Journal of e-Learning, 15(2), 188-198. http://www.ejel.org/issue/download.html?idArticle $=580$

Bacsich, P., \& O'Hare, D. (2009). University of Derby case study [Executive report]. University of Derby.

Bothwell, E. (2020). Student engagement: How do the US, Europe and Japan compare? Times Higher Education. https://www.timeshighereducation.com/news/student-engagement-how-do-us-europe-andjapan-compare

Braun, V., \& Clarke, V. (2012). Thematic analysis. In H. Cooper, P. M. Camic, D. L. Long, A. T. Panter, D. Rindskopf, \& K. J. Sher (Eds.), APA handbook of research methods in psychology, Vol. 2. Research designs: Quantitative, qualitative, neuropsychological, and biological (pp. 57-71). American Psychological Association. https://doi.org/10.1037/13620-004

Davis, N., \& Rose, R. (2007). Research committee issues brief: Professional development for virtual schooling and online learning. North American Council for Online Learning. https://aurorainstitute.org/resource/professional-development-for-virtual-schooling-and-online-learning/

Department for Education. (2017). Teaching excellence student outcomes framework specification. https://assets.publishing.service.gov.uk/government/uploads/system/uploads/attachment_data/file/658 490/Teaching Excellence and Student Outcomes Framework Specification.pdf

Dziuban, C., Graham, C. R., Moskal, P. D., Norberg, A., \& Sicilia, N. (2018). Blended learning: The new normal and emerging technologies. International Journal of Educational Technology in Higher Education, 15(1), Article 3. https://doi.org/10.1186/s41239-017-0087-5

Gao, J., Zhao, B., Tu, M. and Xiong, Y., (2018). The construction of online learning community for learners' sense of belonging. In Proceedings of the 2018 IEEE 9th International Conference on Software Engineering and Service Science (pp. 1-4). IEEE. https://doi.org/10.1109/ICSESS.2018.8663792

Ge, L., Konana, G. P., \& Tanriverdi, H. (2004). Global sourcing and value chain unbundling. The University of Texas at Austin.

https://faculty.mccombs.utexas.edu/prabhudev.konana/globalsourcing.pdf

Golden, J. E., (2016). Supporting online faculty through communities of practice: Finding the faculty voice. Innovations in Education and Teaching International, 53(1), 84-93. https://doi.org/10.1080/14703297.2014.910129

Higher Education Statistics Agency. (n.d.). Where do HE students study? https://www.hesa.ac.uk/dataand-analysis/students/where-study

Higher Education Statistics Agency. (2020a). Non continuation: UK performance indicators 2018/19. https://www.hesa.ac.uk/data-and-analysis/performance-indicators/non-continuation-1819

Higher Education Statistics Agency. (2020b). Table 2b - Continuing professional development (CPD) and continuing education (CE) courses for business and the community by HE provider and academic year 2014/15 to 2018/19. https://www.hesa.ac.uk/data-and-analysis/providers/businesscommunity/table-2b

King, K. (2002). Educational technology professional development as transformative learning opportunities. Computers \& Education, 39(3), 283-297. https://doi.org/10.1016/S03601315(02)00073-8

Korving, H., Hernández, M., \& De Groot, E. (2016). Look at me and pay attention! A study on the relation between visibility and attention in weblectures. Computers \& Education, 94, 151-161. https://doi.org/10.1016/j.compedu.2015.11.011

Macfarlane, B. (2011). The morphing of academic practice: Unbundling and the rise of the paraacademic. Higher Education Quarterly, 65(1), 59-73. https://doi.org/10.1111/j.14682273.2010.00467.x

Martin, P. (2018). On the horizon. Advance HE. https://charteredabs.org/wpcontent/uploads/2019/05/Advance-HE-report-Horizon-Aug19.pdf

McCowan, T. (2017). Higher education, unbundling, and the end of the university as we know it. Oxford Review of Education, 43(6), 733-748. https://doi.org/10.1080/03054985.2017.1343712 
McLoughlin, C., \& Lee, M. J. (2010). Personalised and self regulated learning in the Web 2.0 era: International exemplars of innovative pedagogy using social software. Australasian Journal of Educational Technology, 26(1), 28-43. https://doi.org/10.14742/ajet.1100

McPhee, I., \& Söderström, T. (2012). Distance, online and campus higher education: Reflections on learning outcomes. Campus-Wide Information Systems, 29(3), 144-155. https://doi.org/10.1108/10650741211243166

Means, B., Toyama, Y., Murphy, R., Bakia, M., \& Jones, K. (2009). Evaluation of evidence-based practices in online learning: A meta-analysis and review of online learning studies. U.S. Department of Education. https://www2.ed.gov/rschstat/eval/tech/evidence-based-practices/finalreport.pdf

Mohr, S. C., \& Shelton, K. (2017). Best practices framework for online faculty professional development: A Delphi study. Online Learning Journal, 21(4). https://doi.org/10.24059/olj.v21i4.1273

Norton, A., \& Cakitaki, B. (2016). Mapping Australian higher education 2016. Grattan Institute. https://www.latrobe.edu.au/ data/assets/pdf file/0009/739206/Norton,-A-And-Cakitaki,-B.-2016Mapping-Australian-higher-education-2016,-Grattan-Institute..pdf

Norton, A., \& Cherastidtham, I. (2014). Mapping Australian higher education, 2014-2015. Grattan Institute. http://grattan.edu.au/report/mapping-australian-higher-education-2014-15/

Norton, P., \& Hathaway, D. (2015). Teachers' online experience: Is there a covert curriculum in online professional development? Journal of Technology and Teacher Education, 23(4), 509-533. https://www.learntechlib.org/primary/p/148296/

Office for Students. (2019). Analysis of degree classifications over time: Changes in graduate attainment 2010-11 to 2017-18. https://www.officeforstudents.org.uk/media/1e9dacce-8812-4ae6-9216$164 \mathrm{e} 0 \mathrm{~d} 817 \mathrm{a} 1 \mathrm{~d} / \mathrm{ofs} 201928$ updatefeb2020.pdf

Office for Students. (2020a). 2019 NSS results by registering provider (full-time). https://www.officeforstudents.org.uk/media/65bfdd49-b142-4bb1-911d2f4dafdc2341/nss taught pt19 cah-19022020.xlsx

Office for Students. (2020b). 2019 NSS results by registering provider (part-time). https://www.officeforstudents.org.uk/media/04c965f7-71c0-4293-9ecea48d2078582d/nss registered pt19 cah-19022020.xlsx

O’Doherty, D., Dromey, M., Lougheed, J., Hannigan, A., Last, J., \& McGrath, D. (2018). Barriers and solutions to online learning in medical education-an integrative review. BMC Medical Education, 18(1), Article 130. https://doi.org/10.1186/s12909-018-1240-0

O'Hagan, C. (2003, March). Implementing learning technologies at the University of Derby, 1989-2003: A case study. Observatory on Borderless Higher Education. http://www.obhe.ac.uk/documents/download?id=691

O'Shea, S., Stone, C., \& Delahunty, J. (2015). "I 'feel'like I am at university even though I am online." Exploring how students narrate their engagement with higher education institutions in an online learning environment. Distance Education, 36(1), 41-58. https://doi.org/10.1080/01587919.2015.1019970

Ossiannilsson, E., Williams, K., Camilleri, A. F., \& Brown, M. (2015). Quality models in online and open education around the globe. State of the art and recommendations. International Council for Open and Distance Education. https://www.pedocs.de/volltexte/2015/10879/pdf/Ossiannilsson et al 2015 Qualitymodels.pdf

Pathak, V., \& Pathak, K. (2010). Reconfiguring the higher education value chain. Management in Education, 24(4), 166-171. https://doi.org/10.1177/0892020610376791

Porter, M. E. (1985). Value chain. The value chain and competitive advantage: Creating and sustaining superior performance. Free Press.

Reilly, J. R., Gallagher-Lepak, S., \& Killion, C. (2012). 'Me and my computer': Emotional factors in online learning. Nursing Education Perspectives, 33, 100-105. https://doi.org/10.5480/1536-5026$\underline{33.2 .100}$

Richardson, J. C., Maeda, Y., Lv, J., \& Caskurlu, S. (2017). Social presence in relation to students' satisfaction and learning in the online environment: A meta-analysis. Computers in Human Behavior, 71, 402-417. https://doi.org/10.1016/j.chb.2017.02.001

Roberts, M. (2004). Producing tomorrow's doctor: The new challenge for today's undergraduate medical curriculum. Journal of Vocational Education and Training, 56(4), 467-484. https://doi.org/10.1080/13636820400200265

Rothblatt, S. (2012). The future isn't waiting. In R. Barnett (Ed.), The future university (pp. 15-25). Routledge. 
Ruth, S. R., Sammons, M., \& Poulin, L. (2007). E-learning at a crossroads-what price quality? Educause Quarterly, 30(2), 32-39. https://er.educause.edu/articles/2007/4/elearning-at-a-crossroadswhat-pricequality

Saadatmand, M., Uhlin, L., Hedberg, M., Åbjörnsson, L., \& Kvarnström, M. (2017). Examining learners' interaction in an open online course through the community of inquiry framework. European Journal of Open, Distance and E-learning, 20(1), 61-79. https://doi.org/10.1515/eurodl-2017-0004

Saldaña, J. (2015). The coding manual for qualitative researchers. Sage.

Salmon, G. (2004). E-Moderating: The key to online learning and teaching. Routledge. https://doi.org/10.4324/9780203465424

Santally, M. I., \& Senteni, A. (2013). Effectiveness of personalised learning paths on students learning experiences in an e-learning environment. European Journal of Open, Distance and E-learning, 16(1), 36-52. https://www.eurodl.org/materials/contrib/2013/Santally Senteni.pdf

Shaw, P. (2018). A practice orientated framework to support successful higher education online learning. In A. Volungeviciene \& A. Szücs (Eds.), Exploring the Micro, Meso and Macro Navigating between dimensions in the digital learning landscape: EDEN 2018 Annual Conference Proceedings (pp. 361369). European Distance and E-Learning Network. https://proceedings.eden-online.org/wpcontent/uploads/2018/06/Annual 2018 Genova Proceedings ISSN.pdf

Shaw, P., Rawlinson, S., \& Sheffield, D. (2020). Exploring the problem of establishing horizon emergent technologies within a higher education institution's operational framework. European Journal of Open, Distance and E-learning, 23(1). https://www.eurodl.org/materials/contrib/2020/Shaw et al.pdf

Sundt, M. (2019, January 30). Professors, ask hard questions of your online providers. Inside Higher Ed. https://www.insidehighered.com/digital-learning/views/2019/01/30/professors-should-ask-hardquestions-their-corporate-online

Swinnerton B., Coop, T., Ivancheva, M., Czerniewicz, L., Morris, N. P., Swartz, R., Walji, S., \& Cliff, A. (2020). The unbundled university: Researching emerging models in an unequal landscape. In N. Dohn, P. Jandrić, T. Ryberg, M. de Laat (Eds.), Mobility, data and learner agency in networked learning: Research in networked learning (pp.19-34) Springer. https://doi.org/10.1007/978-3-030-36911-8 2

Tamkin, P., \& Hillage, J. (1999). Employability and employers: The missing piece of the jigsaw. Institute for Employment Studies. https://www.employment-studies.co.uk/system/files/resources/files/361.pdf

Tight, M. (2010). Are academic workloads increasing? The post-war survey evidence in the UK. Higher Education Quarterly, 64(2), 200-215. https://doi.org/10.1111/j.1468-2273.2009.00433.x

UK Council for International Student Affairs. (2019). International student statistics: UK higher education. https://www.ukcisa.org.uk/Research--Policy/Statistics/International-student-statistics-UKhigher-education

Uppal, M. A., Ali, S., \& Gulliver, S. R. (2018). Factors determining e-learning service quality. British Journal of Educational Technology, 49(3), 412-426. https://doi.org/10.1111/bjet.12552

Wang, W. K. S. (1975). The unbundling of higher education. Duke Law Journal, 24, 53-90. https://scholarship.law.duke.edu/dlj/vol24/iss1/3

Wiss, A., DeLoia, J. A., Posey, L., Waight, N., \& Friedman, L. (2018). Faculty development for online learning using cognitive apprenticeship model. International Journal on Innovations in Online Education, 2(1). https://doi.org/10.1615/IntJInnovOnlineEdu.2018025705

Whitchurch, C. (2008). Shifting identities and blurring boundaries: The emergence of third space professionals in UK higher education. Higher Education Quarterly, 62(4), 377-396. https://doi.org/10.1111/j.1468-2273.2008.00387.x

Corresponding author: Paula Shaw, P.Shaw@derby.ac.uk

Copyright: Articles published in the Australasian Journal of Educational Technology (AJET) are available under Creative Commons Attribution Non-Commercial No Derivatives Licence (CC BYNC-ND 4.0). Authors retain copyright in their work and grant AJET right of first publication under CC BY-NC-ND 4.0.

Please cite as: Shaw, P., Gration, M., Green, P., Rhodes, C., Sheffield, D., \& Stone, J. (2020). Within these hyperporous walls: An examination of a rebundled online learning model of higher education. Australasian Journal of Educational Technology, 36(5), 85-101. https://doi.org/10.14742/ajet.6061 